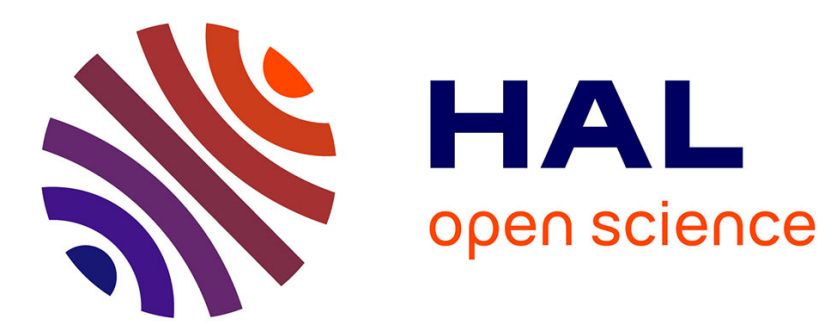

\title{
Spatial competition and the new governance framework in Mabibi (Maputaland): implications for development \\ Sylvain Guyot
}

\section{To cite this version:}

Sylvain Guyot. Spatial competition and the new governance framework in Mabibi (Maputaland): implications for development. The Geographical Journal, 2002, 168 (1), pp.18-32. hal-00201759

HAL Id: hal-00201759

https://hal.science/hal-00201759

Submitted on 24 Apr 2008

HAL is a multi-disciplinary open access archive for the deposit and dissemination of scientific research documents, whether they are published or not. The documents may come from teaching and research institutions in France or abroad, or from public or private research centers.
L'archive ouverte pluridisciplinaire HAL, est destinée au dépôt et à la diffusion de documents scientifiques de niveau recherche, publiés ou non, émanant des établissements d'enseignement et de recherche français ou étrangers, des laboratoires publics ou privés. 


\title{
SPATIAL COMPETITION AND THE NEW GOVERNANCE FRAMEWORK IN MABIBI (MAPUTALAND): IMPLICATIONS FOR DEVELOPMENT
}

\author{
Sylvain GUYOT \\ IRD (Institut de Recherche pour le Développement), \\ University of Zululand \\ ET UMR GEOLAB 6042 CNRS \\ E-mail: sylvain.guyot@unilim.fr
}

\section{Research project and acknowledgements}

\section{Research project}

My work is part of a broader research at two levels. The first: a 'thèse de doctorat' (Guyot 2001) supervised by Prof. Alain Dubresson (Université de Paris X) and Dr. Benoît Antheaume (Institut de Recherche pour le Développement, Johannesburg). The second: a Franco-South African political geography research project directed by Dr Frédéric Giraut entitled "Borderlands: remote areas or cutting edge?" and part of our IRD research group "Localised development: dynamics and regulations" including researchers working in South Africa, Benin, Mali, Brazil, Venezuela.

\section{Acknowledgements}

I would like to thank Prof. Mark Jury (University of Zululand) for his quality of management of the team working on the 'Mabibi UNESCO' project on monitoring coastal biodiversity and also James Mitchell for his corrections and general support. Mrs Yogani Govender-Casanova da Vila provided valuable inputs to the first version of this paper. 


\begin{abstract}
The evolution of the demarcation of the political territories in South Africa has resulted in spatial competition between political structures, conservation authorities and local communities. The current multi-governance policies are attempting to overcome the problems created by the political structures of the apartheid era - during which time the declaration of natural areas for conservation resulted in forced removals and negative perceptions of conservation. The case study of Mabibi, within the confines of the Maputaland coast, is a typical example that reflects the history of the past and the conflicts of the present.
\end{abstract}

\title{
KEYWORDS
}

CONSERVATION, SPATIAL COMPETITION, TERRITORIAL DEMARCATION, GOVERNANCE, MAPUTALAND, SOUTH AFRICA

\section{INTRODUCTION}

The aim of this paper is to discuss the link between spatial competition and the new postapartheid governance framework in terms of its implications for development, with special reference being paid to Mabibi in eastern Maputaland, South Africa. Spatial competition (or disputes over areas) has strong territorial implications, especially in South Africa (Ramutsindela 2001). The paper attempts to list spatially the various activities found in a specific place (e.g. activities related to industry, tourism, communities, nature reserves), and to see whether rational co-existence or competition is taking place, or is even possible (Koch $\&$ Cock 1991). Spatial competition can be acknowledged or claimed (such as when mining companies establish new mines at the expense of the environment) or it can be disguised within politically correct discourse. Spatial competition can also be understood as simply being what the project or the forecast of spatial evolution is about (Guyot 2001). In Mabibi, spatial competition becomes a matter of who has access to the available natural resources and how they are used; and basically entails a conflict between community-based extraction versus conservation in the arena of tourism development (Govender 2001).

The new post-apartheid governance framework has to be understood with reference to the demarcation of the new administrative and management boundaries (Demarcation Board 2000). Its main aim is to promote spatial equity throughout the country. However, does decentralisation imply a process whereby local communities become autonomous or abdicate the management of environmental problems (e.g. in terms of respecting a regulation)? (Guyot 2001) At Mabibi the question is similar to that over much of sub-Saharan Africa: How can the community benefit from conservation without the frustrations arising from conflicts of interests? (AFRA 1990, Compagnon \& Constantin 2000, Draper 1998, Felgate 1982, Fritz 1996). Our research context is favourable to the 'new conservation' concept promulgated by the IUCN: "The first aim of a sustainable conservation requires community involvement within co-operative management structures" (CORD 1991, Davion 1996, Mountain 1990, Rey 2001, Sandwith 2001). In this paper our contribution to 'new conservation' is to analyse why is there still a gap between theory and practice with reference to community involvement?

Maputaland extends from $28^{\circ}$ to $26^{\circ}$ South along the eastern coast of South Africa. While it is rich in natural resources, this part of Kwazulu-Natal is poor when measured by socioeconomic standards (Bruton 1980). For instance, according to the Demarcation Board, 89\% of 
the population of the whole Maputaland ${ }^{1}$ get less than Rand $18000(\approx 1800$ US\$) per year compared to 43, 46 and 27 per cent for the Durban, Johannesburg and Cape Town Metropolitan Areas.

The study area - Mabibi - is found within Maputaland along its coastal belt. This coastal belt is, in many ways, the most attractive part of Maputaland and has great potential for tourism development. It is characterised by five different ecosystems. The coastline comprising sand beaches and a tidal zone rich in corals and reef life. Dune forests consist of tropical and subtropical evergreen trees growing on dunes which reach 70 to $120 \mathrm{~m}$ in height. Grasslands are found between the freshwater lakes (which comprise a separate aquatic ecosystem) and the dune forests. A major arboreal component of the grassland ecosystem is the Lala palm which are used traditionally to make palm wine. Swamp forests occur adjacent to the lakes. The indigenous population has traditionally settled in the grasslands which are, along with the swamp forests, the location of vegetable gardens. The dune forest has been used traditionally for firewood and the sea has provided marine resources, particularly fish and mussels. The recent development of tourism has meant that settlements have developed near the beaches.

\section{METHODOLOGICAL ASPECTS}

\section{Methodology}

Our methodology refers to that developed by the French anthropologist Jean-Pierre Olivier de Sardan $(1997,1998)$. We used a qualitative approach based on interviews with representative and significant stakeholders and on arena observations. Some interviewees preferred to stay anonymous. Therefore I will refer to interviewees only by their positions.

Three levels of stakeholders are involved in spatial competition: national, provincial and municipal (or local). While the local level will obviously be dealt with as a priority in our discussion as it is a case study based around one community, relationships between and potential conflicts with the two other levels of stakeholders are also central to the paper. At this stage it is important to define these stakeholders who fall mainly into two categories. First, decision-making actors (political, technical and economic for each sector) and, secondly, regulating actors (e.g. associations, citizens.). Classifying traditional leaders in this two-fold division proved problematic, and I have categorised them as a further category of stakeholders with their own strategies and dynamics.

One could ask why there is no concordance between the discourse of stakeholders and what they put into practice (e.g. the logic of stakeholders and the logic of their choices). To answer this it is essential to consider the temporary nature of their actions in order to give meaning to the contradictions that acknowledged (i.e. the trinomial of recent past - present - future). The difference between 'words and practice' also has to do with the relationships between technical decision-making power (which mainly involves White South Africans): mastering skills; conserving acquired advantages; the elected political power (which mainly involves Black South Africans); and the transformation conquest (Guyot 2001).

Questionnaires were distributed to a random sample of people in the study area. Seventy-five questionnaires were conducted within a population estimated at 200 households $^{2}$ (Govender

\footnotetext{
${ }^{1}$ Umkhanyakude District Municipality [DC27]

${ }^{2}$ the estimate is between 1500 and 2000 inhabitants.
} 
1999, Jury et al 2001, Mthembu 2001). The interviews took place via the intermediary of a local translator for the Zulu-speaking stakeholders.

\section{MAPUTALAND: CONSTRAINTS AND OPPORTUNITIES}

\section{Constraints}

Mabibi is located on the North Eastern coast of South Africa (Figure 1). The entire coastline of Maputaland from the Mozambican border to the St Lucia Estuary (Figure 2) is historically considered as confined in relation to the entire Kwazulu-Natal coast, and in opposition to the more developed southern part. Many physical constraints (e.g. subtropical humid climate and its related endemic diseases such as malaria and tick bite fever, natural obstacles such as lakes and dunes) inhibit the development of the Mabibi area. The sandy soils are naturally poor and the slash-and-burn method of cultivation that is traditionally used by farmers (photo 1), exaggerates the natural lack of nutrients (Mountain 1990). Maize and peanuts are the major subsistence crops in the area. The remainder of the diet mainly comprises fish and shellfish and natural resource extraction from dune forests.

\section{FIGURE 1}

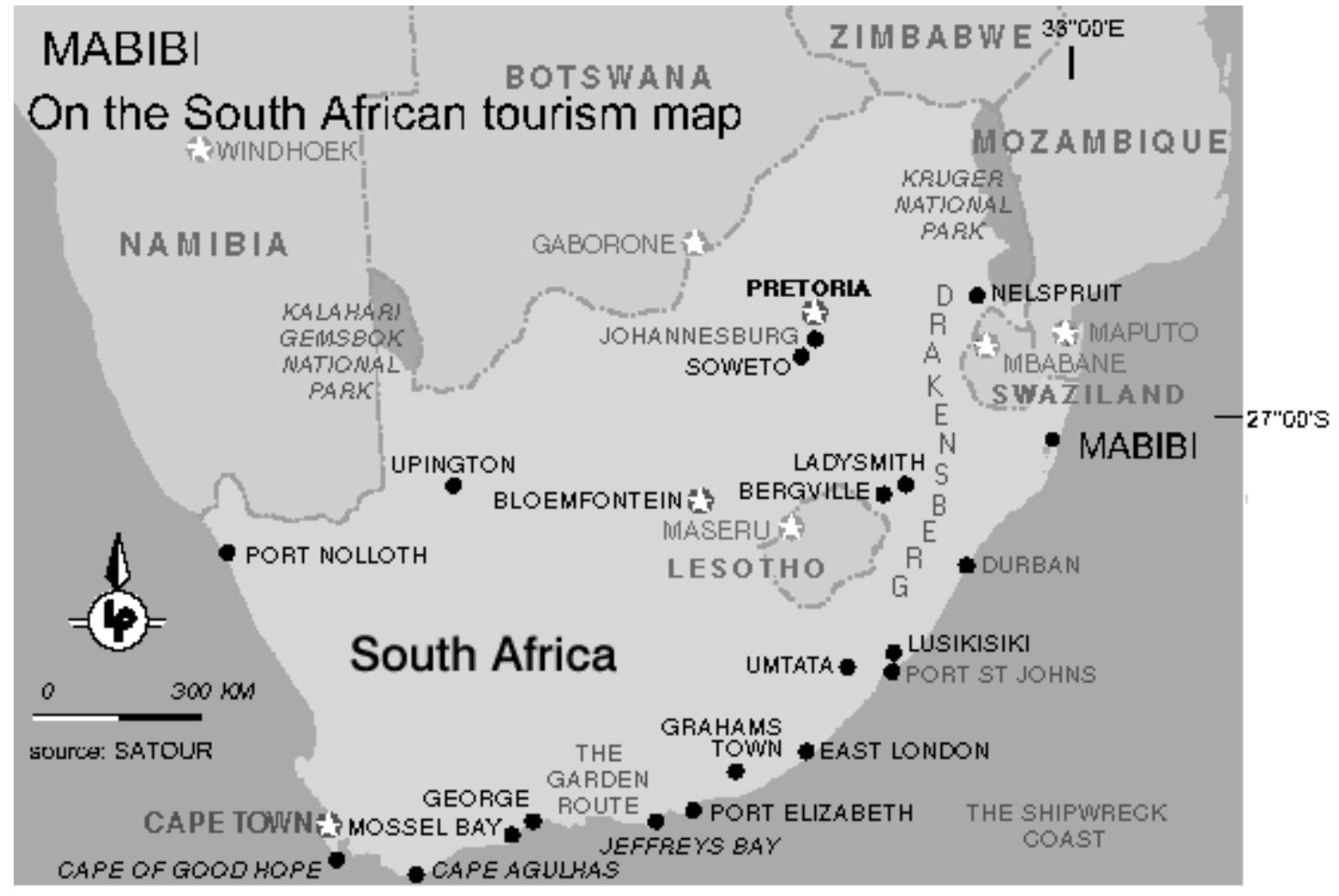

The community of Mabibi is located between the Indian Ocean and Lake Sibaya, and is accessible only by four-wheel drive vehicles (Figure 3 ). The richest residents organise payingshuttle services with their own four-wheel drive vehicles. There is no mobile-phone network in the area; and a mobile clinic and a post office are the only government infrastructure available to the population. The poor communications contribute to the isolation of the territory (Giraut 2001). Water supply is delivered through public taps - part of a programme funded by the European Union (Photo 4). 
FIGURE 2 
POLITICAL TERRITORIES IN RELATION

TO MABIBI DURING THE APARTHEID ERA (1950-1994)

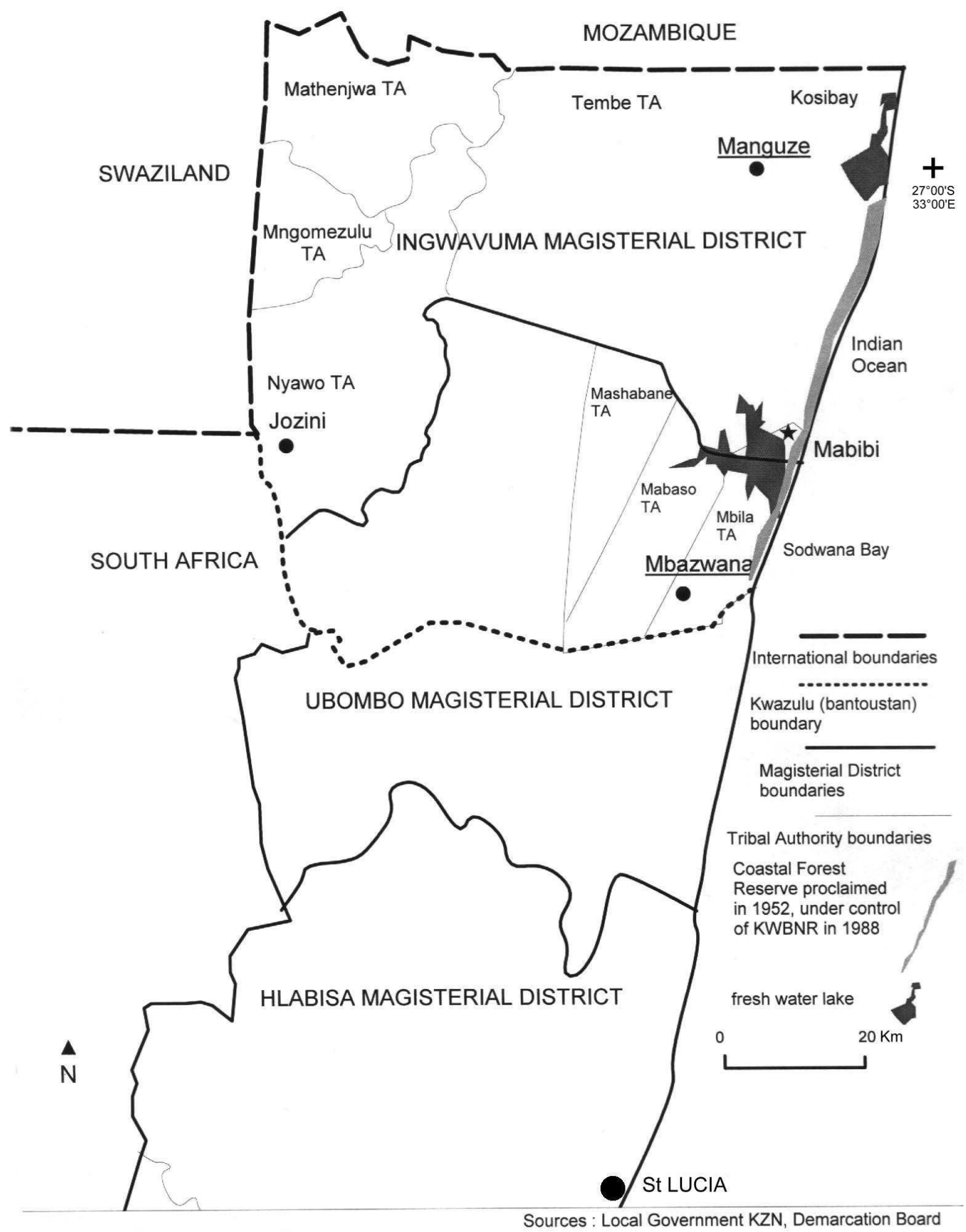

Opportunities 
Although poor in services, Mabibi is surrounded by valuable assets such as pristine subtropical dune forest containing many rare species (Govender 2001) and rich coral life offshore - including more than 30 species of tropical fish (Jury et al. 2001). Other permanent attractions include the scenery (Photos 2 and 3 ) and a year-round warm climate with temperatures ranging from $12-24^{\circ} \mathrm{c}$ in winter to $21-30^{\circ} \mathrm{C}$ in summer. The offshore water is warm $\left(23-26^{\circ} \mathrm{C}\right)$ due to the effects of the Agulhas Current (Jury et al. 2001). The combination of these assets provides a potentially tourist-friendly environment. However, at present just a small campsite, managed by Kwazulu-Natal Wildlife, can accommodate tourists at Mabibi. The natural patrimony has not been preserved because of 'massive extraction' by the community (Govender 2001). Consequently, the spatial conflict between traditional uses of natural resources and conservation, as a route toward tourism development, exists. It is pertinent to discuss the origins of this conflict and what is being done to address it?

\section{FIGURE 3}

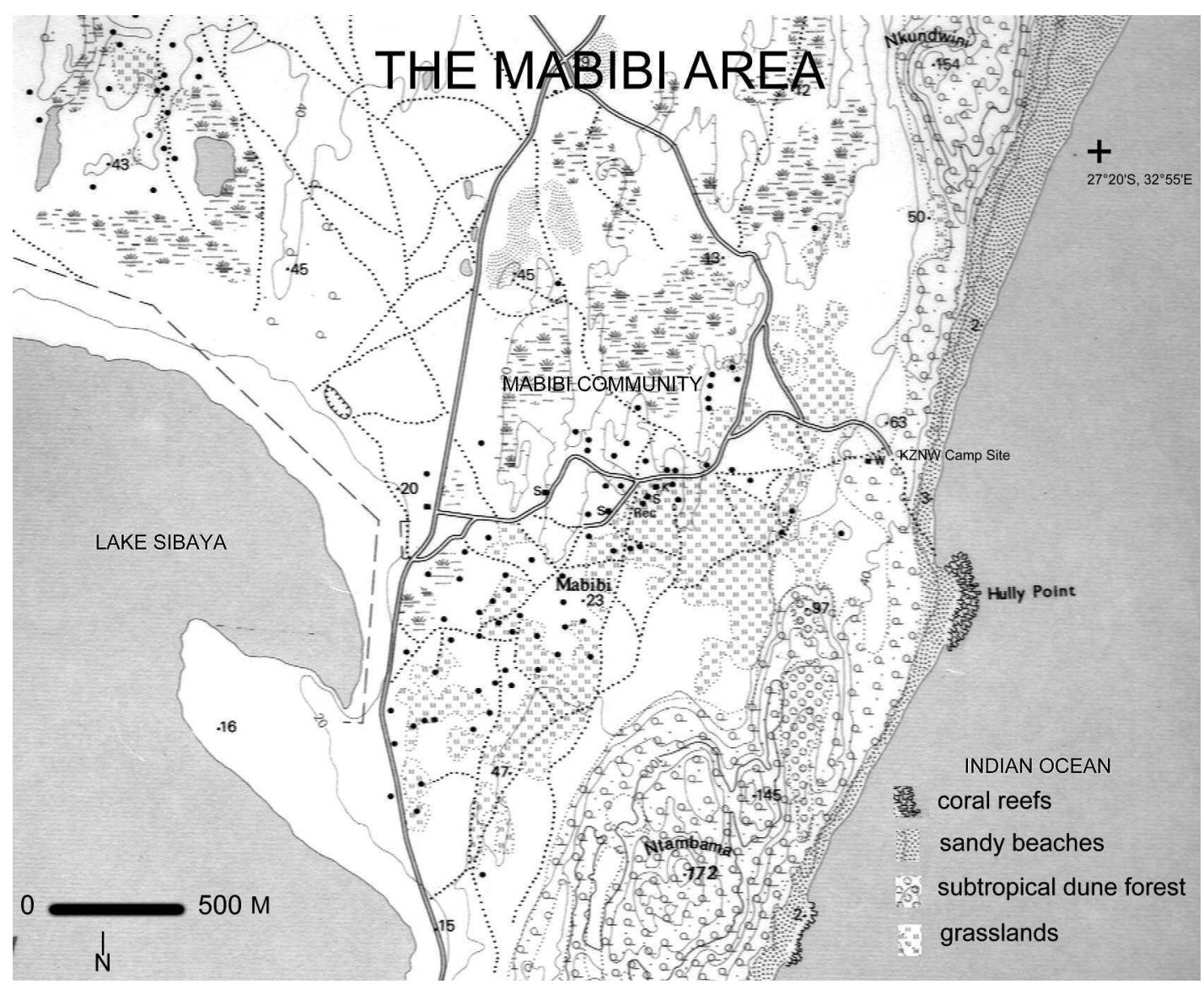

\section{THE ORIGINS OF SPATIAL COMPETITION AND THE LACK OF DEVELOPMENT}

\section{Mabibi during the apartheid era (1948-1994)}

Prior to 1972, before the creation of the Kwazulu Homeland, the provincial government administered this part of Natal Province at a distance. It was considered a 'black population territory'. In 1952 the area north of St Lucia was proclaimed the Coastal Forest Reserve; this included the dune forests close to Mabibi. The Mabibi community acquired the status of a 'black reserve' but was losing, in theory, its access to 'Nature' and to its natural resource base. 
The administrative affairs of the people in Mabibi were controlled by the Ingwavuma Magisterial District based in Manguzi (Figure 2) at this time. In the 1960s governance was handed over to the Tribal Authority ${ }^{3}$, especially in respect of infrastructure development. A Tribal Authority consists of a chief (Inkhosi) who delegates his power, with the agreement of the people, to an Induna. The latter person is in charge of a ward - piece of land within the boundaries of the Tribal Authority (Crouzel 1999). For Mabibi, the situation is unique in that the land is the property of the Tembe Tribal Authority (based at Manguzi) but is managed by the Mbila Tribal Authority (based at Mbazwana) with Indunas from the Mdletshe family ${ }^{4}$. This explains why Mabibi is a part of the Ingwavuma Magisterial District, but the Induna is from Mabibi in the Mbila Tribal Authority. The effect of this dual authority is that if the people in Mabibi wanted to build something in the pats (e.g. a community hall or a sports field) they had to refer to the authorities in both Manguzi and Mbazwana which created delays.

After 1972, the area north of Sodwana Bay, which includes Mbazwana was integrated in the Homeland Kwazulu - an officially named 'self government territory' The poor level of development in Maputaland indicates that this region was not a high priority for the Inkhata Freedom Party government - based in Ulundi - at this time. The reasons for this most likely emanate from the high proportion of Tonga in the area in comparison to Zulus, and its geographically peripheral location. This government managed the area with two purposes in mind: first, in relation to the war in Mozambique, as military area, and, secondly, for conservation.

In the 1980s, the Kwazulu government realised that it would be beneficial in terms of self government autonomy to have the control of its conservation areas and also to be able to proclaim new parks - as happened at Tembe in 1984 and Kosi Bay in 1989 (Rey 2001). The control of the Coastal Forest Reserve passed from the Natal Parks Board to the Kwazulu Bureau of Natural Resources (KBNR) in 1988. Since this time there has been no consultation between KBNR and the communities concerning the use of natural resources within its conservation areas (AFRA 1990), and this has resulted in strong spatial competition. In summary, the level of development did not improve with the transition to a homeland government, simply the 'name' and the 'colour' of the power changed.

In 1985, Regional Services Councils (RSC) were the main form of regional governance throughout South Africa with the exception of Kwazulu-Natal. The function of RSCs was to divide the provinces into regions to implement the delivery of services such as water or sanitation. The implementation of RSCs was delayed in Natal-Kwazulu in order to accommodate the political initiatives embodied by the Indaba ${ }^{5}$. In the meantime developmental needs were becoming increasingly urgent. (Juta's RSC Report 1990). The Kwazulu and Natal Joint Services Board was the name finally decided upon for this new level of management and, in 1990, Mabibi, Kosi Bay, Richards Bay and Ulundi were joined to form part of the Zululand Region, one of the RSCs in Kwazulu-Natal. Prior to 1994, this was

\footnotetext{
${ }^{3}$ During the apartheid era the traditional leaders were appointed by the government in Pretoria and received grants for local development (Crouzel 1999).

4 "The Mdletshe claim that it was only with the assistance of the Europeans that the Tembe-Thonga gained dominance over them. They tell a story of how, during the latter part of the nineteenth century, a European Magistrate came down to Lake Sibaya and spoke to Mabibi, the Mdletshe Chief. (...) He went on to persuade the Chief to subject himself and his people to the Tembe. In this way, the magistrate argued, they would retain a large measure of their independence and avoid being driven off their land by the stronger tribes to the north of them. (...)" (Felgate 1982). The Mdletshe have an alliance with the Mbila Tribal Authority.

${ }^{5}$ Indaba means "meeting together".
} 
the only joint management structure in Kwazulu-Natal. With this new form of governance Mabibi suffered because due to its proximity to the Coastal Forest Reserve the administration thought it was the responsibility of the conservation agencies to provide basic services (Interview with conservation services representatives, Pietermaritzburg, 23-01-2001).

\section{The political end of apartheid}

Since the democratic elections in 1994, the national priorities for development changed. The national policy of the reconstruction and development program indicates that an equitable share of prosperity exists for all, especially in underdeveloped rural areas. Since 1996, with the creation of the Regional Councils, new political demarcations at a regional level have been created. Mabibi was included in the Uthungulu Regional Council based at Richards Bay. This council deals with the area from the Mozambique border in the North and Richards Bay in the South. Its aims are to provide water and electricity in the rural areas and to promote tourism. However, there has been no effective co-operation the between conservation services and the regional authorities to implement a common strategy (Interview with Uthungulu Regional Council officials, Richards Bay 11-10-2001).

At a local level the urban areas passed from the jurisdiction of the Transitional Local Councils. However no local authority was elected for rural areas of Kwazulu-Natal.

"In its Kwazulu-Natal fief $f^{6}$, the IFP maintained that the areas of the Province under Traditional Jurisdiction, the Tribal Authority had to remain as the only local structure of power excluding the election of municipal councils."(Crouzel 1999).

Therefore Mabibi remains between its two Tribal Authorities in the context of the Magisterial Districts.

Contemporaneously the Kwazulu Bureau of Natural Resources began to amalgamate with the Natal Park Board. The amalgamated conservation body (Kwazulu-Natal Nature Conservation Services - KZNNCS) manages the Coastal Forest Reserve. One idea which originated in its head office in Pietermaritzburg was to diffuse the benefits of development from the protected areas to the neighbouring communities. In Mabibi this resulted in KZNNCS employing local community members as camp managers, (Interview with KZNNCS representatives, Mabibi 28-03-2001). However, the duration of the transition era was insufficient to see development (e.g. infrastructure and tourism) benefits from the Uthungulu Regional Council or the KZNNCS Moreover, spatial competition has arisen from the continuing tensions between communities and the conservation services.

\section{PHOTO 1 : Agriculture practices at Mabibi}

\footnotetext{
${ }^{6}$ French word for an "aristocratic owned" piece of land
} 


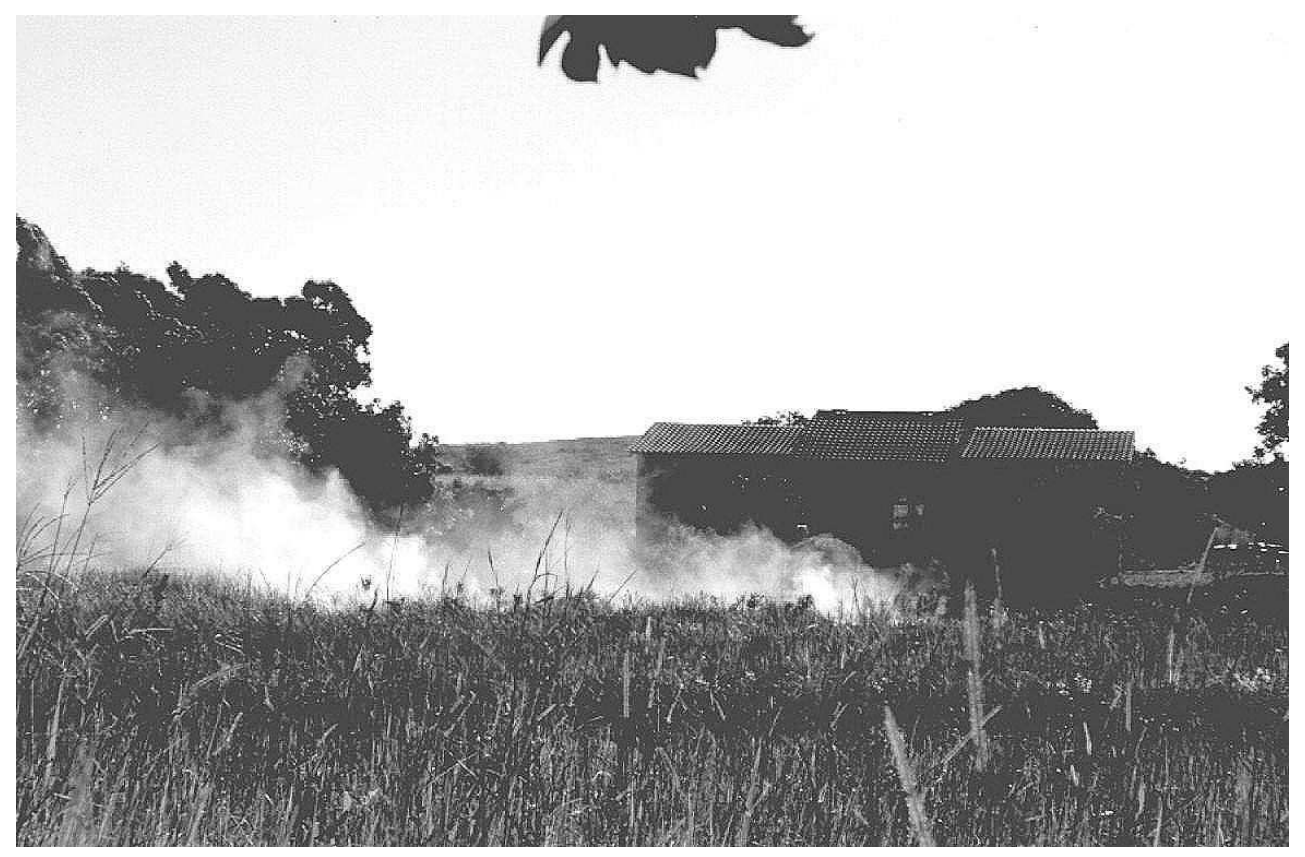

PHOTO 2: View on the Lake Sibaya

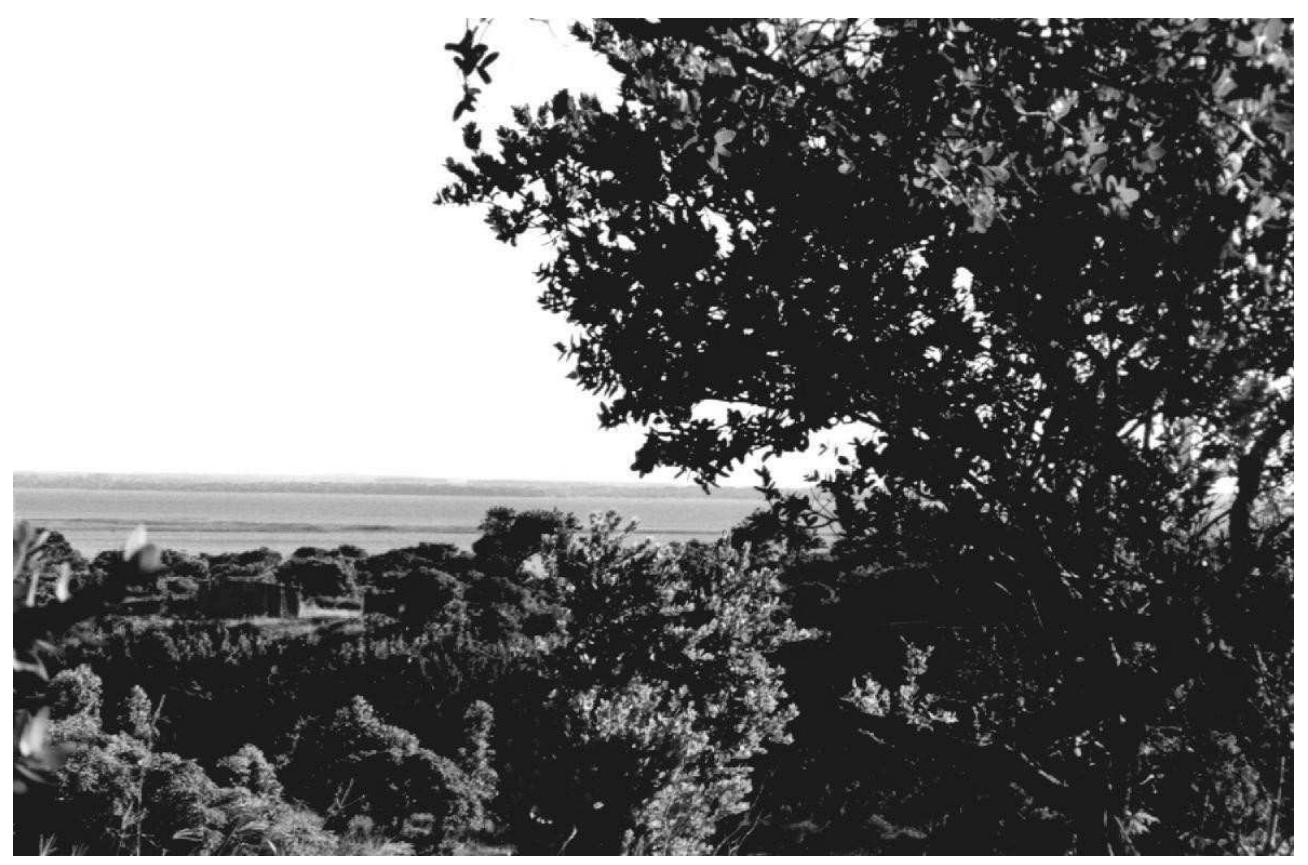

\section{SPATIAL COMPETITION ON THE GROUND}

\section{Results of questionnaires and interviews}

Questionnaires with open-ended questions were administered mainly in 1999 within the political and demarcation contexts of the transition era (Govender 1999), and again in 2000 and 2001 within the context of the new demarcation (Jury et al 2001, Mthembu 2001). In total 70 questionnaires were conducted with community members and five with KZNNCS staff. Longer interviews tackling issues in more depth were conducted in parallel with a sample of stakeholders (these interviews are referenced in the main body of the text). 
From the interviews carried out with community members and KZNNCS staff there was no indication that any of the conservation measures implemented had had any positive impacts on community development. Of all the people interviewed within the community, $90 \%$ felt that restrictions on the use of land for planting crops impeded community development. With the strict land use controls implemented by KZNNCS (e.g. the official regulations banning the collection and use of natural resources from the dune forest, restrictions on cutting incema grass which is used to make crafts to once per year in May), the community has been severely affected since food production has been reduced. This has resulted in families moving out of the community to search for work in urban centres. In some homesteads, only the father traditionally the breadwinner - has left home to seek employment in urban areas, but in other cases has resulted in the breakdown of family units. Most people (95\%) interviewed felt that the conservation measures implemented at Mabibi - such as the erection of fences, controls on access, official regulations regarding the use of dune forest resources - needed to be reviewed to take the local communities into account. By placing restrictions on land-use, building of farm fences and preventing them from killing wild animals which destroy their crops, they are not able to sustain their household food requirements. Controls in the name of conservation that have been implemented on the harvesting of plants for medicinal purposes have also been a controversial issue. Most members (75\%) interviewed indicated that certain indigenous plants such as Phyllanthos spp (which is used for its antibacterial and antiviral actions) and Phoenix reclinata (which is used to treat patients with pleurisy) (Govender 2001) are required for medical purposes. Collection restrictions have resulted in community members illegally collecting these plants from the coastal forests.

Although there are no restrictions on the amount of fish or mussels that can be harvested for daily household consumption, restrictions have been placed on harvesting and fishing for commercial purposes. Both KZNNCS staff and community members were against the suggestion that fishing permits should be introduced in the area. They felt that these permits would not encourage tourists to visit the camps, and that they would also result in local people being excluded from fishing since they will not be able to afford the permits. With its new World Heritage Status the area will be forced to adopt fishing restrictions in the near future.

A high proportion $(75 \%)$ of the people interviewed from within the community have a negative perception about the KZNNCS, although they understand the need for conservation in the context of attracting tourists to the area. Emotions ran high (e.g. the adoption of defensive attitudes, protest meetings organised with the Induna) when members of the community were questioned about the erection of fences around the marine reserve ${ }^{7}$. The vast majority (95\%) of the members interviewed stated that the erection of fences would prevent them having access to the beach where they fish and harvest mussels. Additionally it would restrict the movement of their cattle.

\section{PHOTO 3: The Hully Point and the Indian Ocean}

\footnotetext{
${ }^{7}$ Maputaland Marine Reserve was declared as a national protected area in 1979 following the St Lucia Marine Reserve.
} 


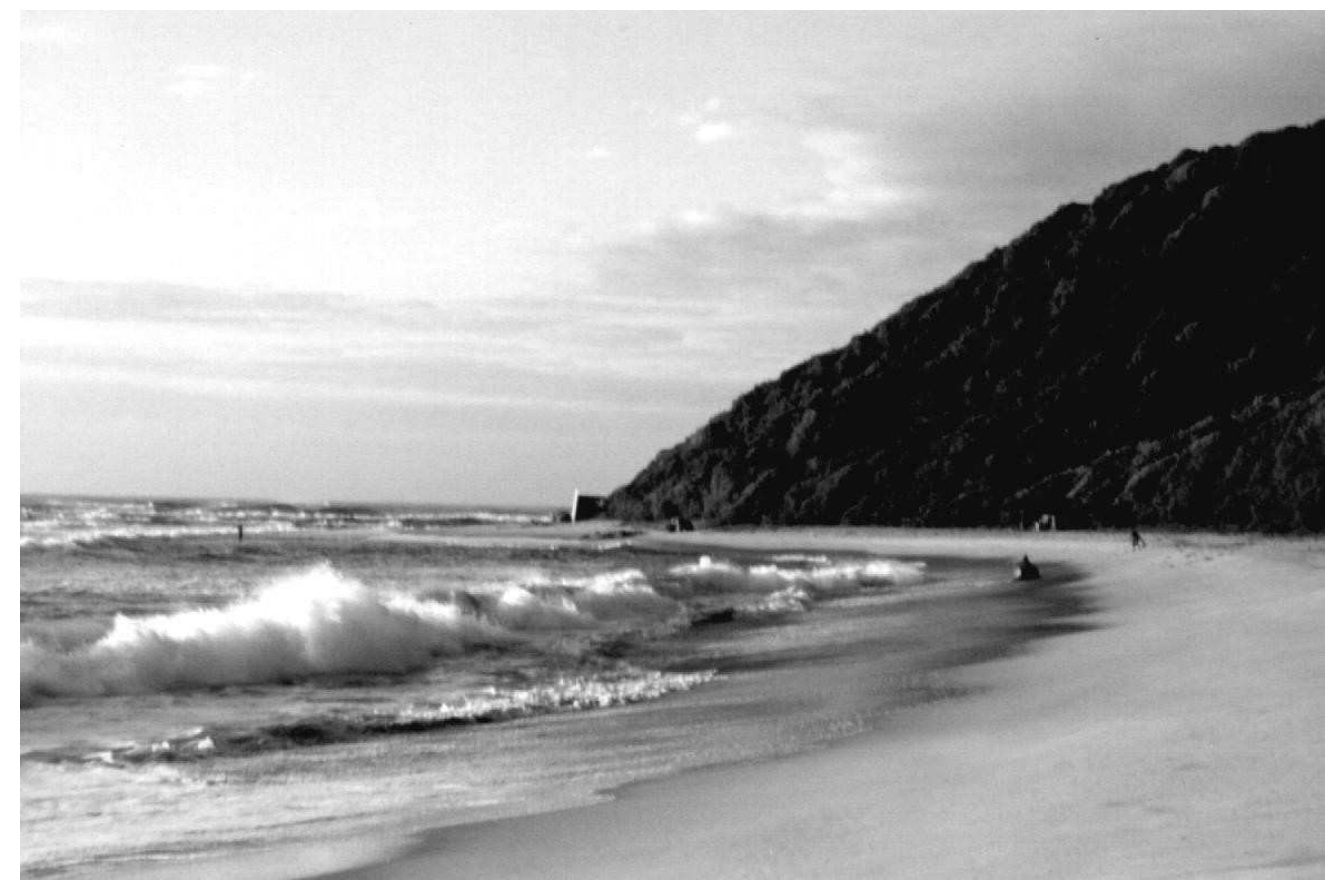

\section{PHOTO 4 : The community tap}

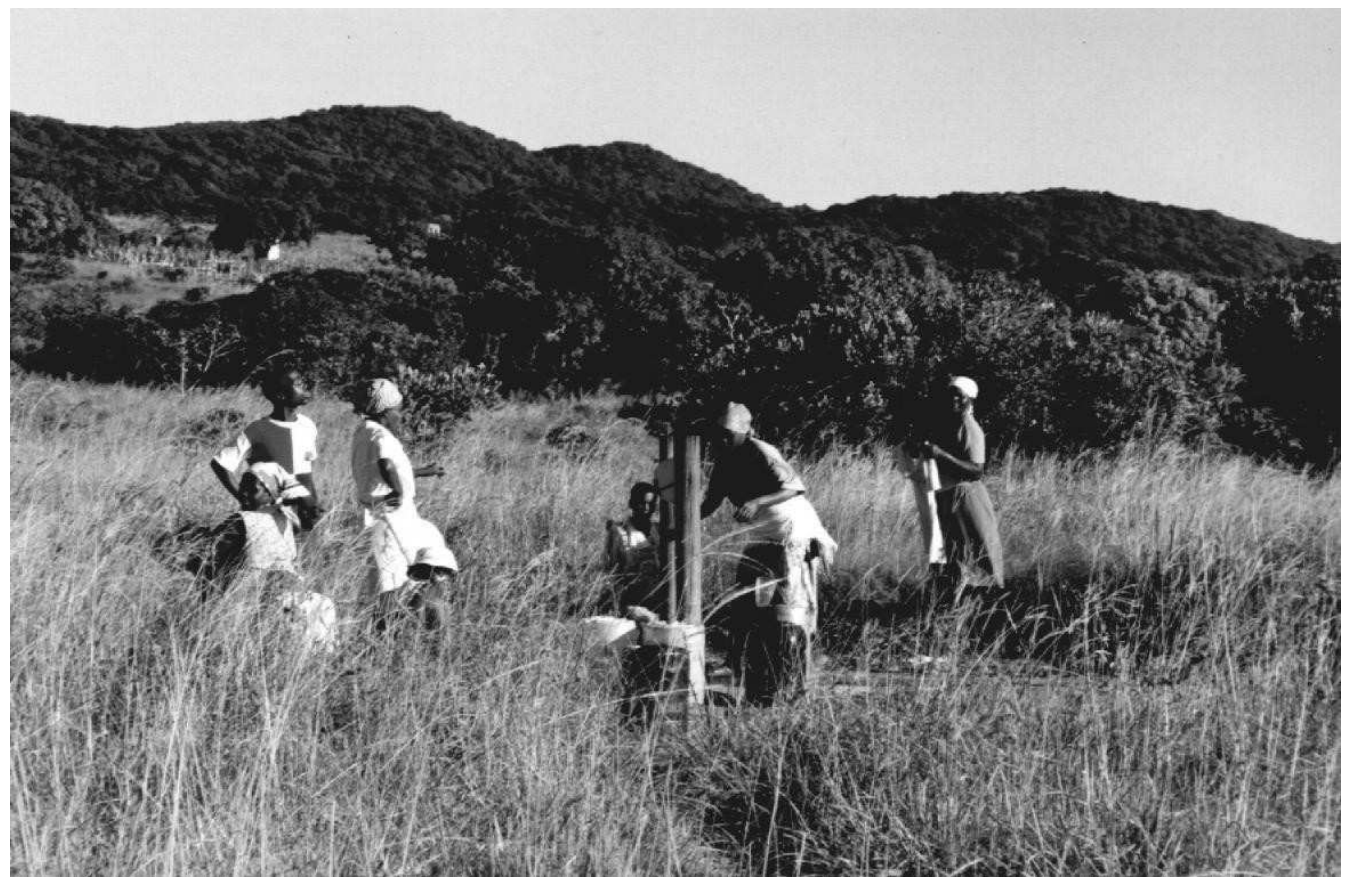

Development demands: differences of priorities 
Staff from KZNNCS and community members were asked to rank their development priorities for the area (Table 1).

Table 1: Ranking of developments that are thought to lead to community improvements by community members and KZNNCS staff (Source: questionnaires, Govender 1999)

\begin{tabular}{|l|l|}
\hline COMMUNITY MEMBERS & KZNNCS STAFF \\
\hline 1. improve roads & 1. increase tourist facilities \\
\hline 2. creation of jobs & 2. increase employment \\
\hline 3. build a training centre & 3. provide houses \\
\hline 4. improve health care services & 4. improve clinic \\
\hline 5. more schools & 5. improve schools \\
\hline
\end{tabular}

Residents prioritised roads on the grounds that they improve the community developments in the area by improving the accessibility. Improved access would have a cumulative effect in that it would attract more tourists and tourist developers to the area. Thus it would improve employment, resulting in more money being brought into the community. The creation of employment opportunities would reduce the rural-to-urban migration that is presently facing the community. Members of the community realised the need to educate adults as an important requisite for improving community development and suggested that a training centre be built for this purpose. The KZNNCS staff saw an increase in tourist facilities, which includes building a new road, as the highest priority. In this matter, the community demands are not different, as new development would benefit everybody living in the area.

The data in Tables 2 and 3 shows that both the members of the community and KZNNCS staff see the potential for larger scale tourist development in the area.

Table 2: Types of tourist infrastructure structure and activities in Mabibi at the present time

\begin{tabular}{|l|}
\hline Tourist structures and activities \\
\hline 1. Camps \\
\hline 2. Nature trails \\
\hline 3. Fishing $\backslash$ Angling \\
\hline 4. Boat Trips \\
\hline 5. Diving $\backslash$ Snorkelling \\
\hline
\end{tabular}

Table 3: Ranking of developments that are thought to lead to community improvements by community members and KZNNCS staff (Source: questionnaires, Govender 1999)

\begin{tabular}{|l|l|}
\hline COMMUNITY MEMBERS & KZNNCS STAFF \\
\hline 1. cultural & 1. cultural tourism \\
\hline 2. boating $\backslash$ motorised trails & 2. more camps \\
\hline 3. horse riding & 3. snorkelling \\
\hline 4. fishing & \\
\hline 5. bird watching & \\
\hline
\end{tabular}

The tourist activities in the area are not yet organised, and tourists have to bring their own equipment as only a basic infrastructure is provided at the campsite. There is great potential 
for formalise what it is already possible to do (e.g. nature trails, fishing, snorkelling) and there is also potential to create new attractions, particularly in the area of cultural tourism. The construction of community hall would boost cultural tourism as concerts ${ }^{8}$ and dance, craft and art exhibitions could be organised there. However, this potential for development can only be realised with real co-operation between community members, the Induna, conservation staff and the new political authorities. For this reason, development cannot start without the involvement of rural local governance (McIntosh 1995, Barnes \& Morris 1997). In this respect, 2000 was an important year in terms of political changes, especially at a local level. A new demarcation has been implemented and Mabibi is now part of the Greater St Lucia Wetland Park which has been recognised as being part of a World Heritage Area. What are the consequences of these recent changes for both spatial conflicts and for development?

\section{THE GOVERNANCE FRAMEWORK Prioritising tourism development within a World Heritage context.}

\section{The implementation of a complex governance framework}

In Table 4 the complexity of the framework for the new governance for Mabibi is illustrated. All of the different levels of power noted in the table have some kind of management responsibilities for the area but with contrasting financial abilities to drive development and different levels of legitimacy in the eyes of the community. The only level at which development can be initiated - the national level - means that it is difficult for local people to initiate development. The bodies that are close to the people (i.e. at the local level) do not have the financial resources to promote real development alternatives. The political differences at the different levels, e.g. ANC nationally and IFP ${ }^{9}$ locally, could be also a source of rivalry and competition over resources, especially area with a majority of IFP voters.

Table 4 : The new governance framework for Mabibi

\footnotetext{
${ }^{8}$ The local primary school already has an impressive choir directed by one of the teacher - Victor Thwala. This work needs to be promoted (Interview and school visit, 30-11-2001).

${ }^{9}$ IFP ( Inkhata Freedom Party) is the opposition party to the ANC at a local level in Kwazulu-Natal and part of the governmental majority at a provincial and national level.
} 


\begin{tabular}{|c|c|c|c|}
\hline Authority level & Governance body & $\begin{array}{l}\text { Financial ability to drive } \\
\text { development }\end{array}$ & Legitimacy \\
\hline International & UNESCO & $\begin{array}{l}\text { No development } \\
\text { responsibility, but has a } \\
\text { regulatory capacity with } \\
\text { regard to the natural } \\
\text { preservation of the site }\end{array}$ & International recognition \\
\hline \multirow[t]{2}{*}{ National } & $\begin{array}{l}\text { Greater St Lucia Wetland } \\
\text { Park } \\
\text { (GSLWP) }\end{array}$ & $\begin{array}{l}\text { General management of } \\
\text { the new park in } \\
\text { collaboration with KZNW } \\
\text { on the conservation side, } \\
\text { the Provincial Minister of } \\
\text { Economic Affairs and } \\
\text { Tourism, and LSDI on the } \\
\text { development side. }\end{array}$ & \multirow[t]{2}{*}{$\begin{array}{l}\text { National government } \\
\text { (ANC) agencies, } \\
\text { No direct election from the } \\
\text { people. }\end{array}$} \\
\hline & $\begin{array}{l}\text { Lubombo Spatial } \\
\text { Development Initiative } \\
\text { (LSDI) }\end{array}$ & $\begin{array}{l}\text { High financial capacity. } \\
\text { Infrastructure } \\
\text { development agency plus } \\
\text { leader in joint-venture } \\
\text { tourism projects }\end{array}$ & \\
\hline Provincial & $\begin{array}{l}\text { KwaZulu-Natal Wildlife } \\
\text { (KZNW), former } \\
\text { KZNNCS. }\end{array}$ & $\begin{array}{l}\text { Low financial capacity but } \\
\text { new local involvement } \\
\text { respecting new IUCN } \\
\text { principles. }\end{array}$ & $\begin{array}{l}\text { Provincial conservation } \\
\text { agency, } \\
\text { Low popular legitimacy at } \\
\text { this stage }\end{array}$ \\
\hline Regional & $\begin{array}{l}\text { District Council } 27 \\
\text { District Management Area }\end{array}$ & $\begin{array}{l}\text { Low financial capacity (no } \\
\text { base build on rates or } \\
\text { levies) }\end{array}$ & $\begin{array}{l}\text { Elected municipal council } \\
\text { (currently Inkhata } \\
\text { Freedom Party - IFP) }\end{array}$ \\
\hline \multirow[t]{2}{*}{ Local } & $\begin{array}{l}\text { Neighbouring Local } \\
\text { Municipality (KZ 271) }\end{array}$ & $\begin{array}{l}\text { Low financial capacity (no } \\
\text { base built on rates or } \\
\text { levies) }\end{array}$ & $\begin{array}{l}\text { Elected municipal council } \\
\text { (currently Inkhata } \\
\text { Freedom Party - IFP) }\end{array}$ \\
\hline & $\begin{array}{l}\text { Mbila Tribal Authority } \\
\text { ("management") } \\
\text { Tembe Tribal Authority } \\
\text { (land ownership) }\end{array}$ & None & $\begin{array}{l}\text { Legitimacy is a sensitive } \\
\text { issue: either a high } \\
\text { traditional legitimacy or a } \\
\text { non-democratic autocracy }\end{array}$ \\
\hline
\end{tabular}

1- We do not include in this table the two main stakeholders, the residents and the tourists, who are part of the governance sphere. The residents have powers through elections and popular protest. The tourists represent a (potentially) important source of financial inputs.

The full division of powers and functions between these different levels and bodies is still evolving.

\section{A new national authority with international ambitions}

In 2000, the coastline between Kosi Bay in the North and Mapelane in the South was recognised as a World Heritage Site by the UNESCO (Figure 4). Mabibi is located within this World Heritage Site. In the context of this newly acquired status, many conservationists now see an opportunity to implement a single conservation area that extends from the Mozambican border to St Lucia estuary, as opposed to the existing fragmented pockets ${ }^{10}$. A new national authority was proclaimed for the management of the Greater St Lucia Wetland Park (GSLWP). This new authority is "an autonomous body legally established to manage the GSLWP and take responsibility for conserving its World Heritage Status"11. The GSLWP is an 'anchor' project of the Lubombo Spatial Development Initiative (LSDI) ${ }^{12}$ with Kwazulu Natal Wildlife (the new name for KZNNCS) and the Kwazulu-Natal Tourism Authority. The

\footnotetext{
${ }^{10}$ Kosi Bay Nature Reserve, Coastal Forest Nature Reserve, Sodwana Bay National Park, Maputaland Marine Reserve, St Lucia Marine Reserve, St Lucia Game Reserve, St Lucia Park, Mapelane Nature Reserve, Mkuze Game Reserve

${ }^{11}$ Government Notice 4477 of 2000, Government Gazette No 21778, vol. 425, Pretoria, 24 November 2000

12 This Initiative is attempting to improve the road infrastructure and develop ecotourism nodes in the Maputaland Region.
} 
close ties between the LSDI and the new authority can be seen in the fact that the LSDI manager is acting CEO for new authority. As a consequence, new development is included directly within the context of the park; and the priority is to create infrastructure and tourist accommodation to attract overseas visitors. The most pertinent question is: Who will really benefit from these developments?

Since the second local elections in South Africa on December $5^{\text {th }} 2000$, the Municipal Demarcation Board changed all the areas of local government to improve service delivery and the redistribution of the prosperity. A District Council now represents the regional level. The former Regional Council was divided into two parts to create this District Council. The new District Council consists of five municipalities at the local level which have amalgamated rural and urban areas. A third level of local government is reserved for the less densely populated areas and the conservation areas. These are District Management Areas (DMA) and they are managed directly by the District Council (Figure 4). One representative is elected from each DMA as councillor to the District Council ${ }^{13}$. Mabibi is now included in a DMA KZDMA 27 - within DC (District Council) 27 (Figure 4). In the interviews, we noticed confusion amongst the local stakeholders concerning the boundaries of these new councils, about the actual existence of the DMA, and about the effective division of powers and functions. This confusion is not conducive to managing the existing conflicts.

Added to this is the fact that the ownership of the land in question is still traditionally the property of the Tembe Tribal Authority (Ingonyama Trust), and the Induna is still a part of the Mbila Tribal Authority. Fortunately the two tribal authorities are now integrated in the same Local Municipality, KZ 271 - Umhlabuyalingana Municipality. The main consequence of these changes in political structures for Mabibi is increased complexity. People will have to deal with this 'multi-governance' and it is pertinent ask what are the direct consequences for development and improvements to the quality of life.

\footnotetext{
13 "People who voted in DMAs had two votes for parties of their choice: (i) for the District as a whole, and (ii) for the DMA representative. The DMA representative is not for a particular area, but for all the DMA voters throughout the District municipality. Given that there is no specific person for the DMA areas (no ward councillor) in practice what should happen is that the District municipality would appoint a person from their council (it could be the DMA representative or even another councillor as they have the right to delegate responsibilities in terms of the Municipal Structures Act.) The DMA is not a legal body, but rather the Category C (District) municipality has all the municipal powers for the DMA areas. There is no real conflict with the national Heritage Authority and I am working with them to sort out any perceived or real problems." (Interview with Mike Sutcliffe, head of the Municipal Demarcation Board 8-04-2001)
} 


\section{FIGURE 4}

THE PRESENT POLITICAL TERRITORIES

IN RELATION TO MABIBI (2001)

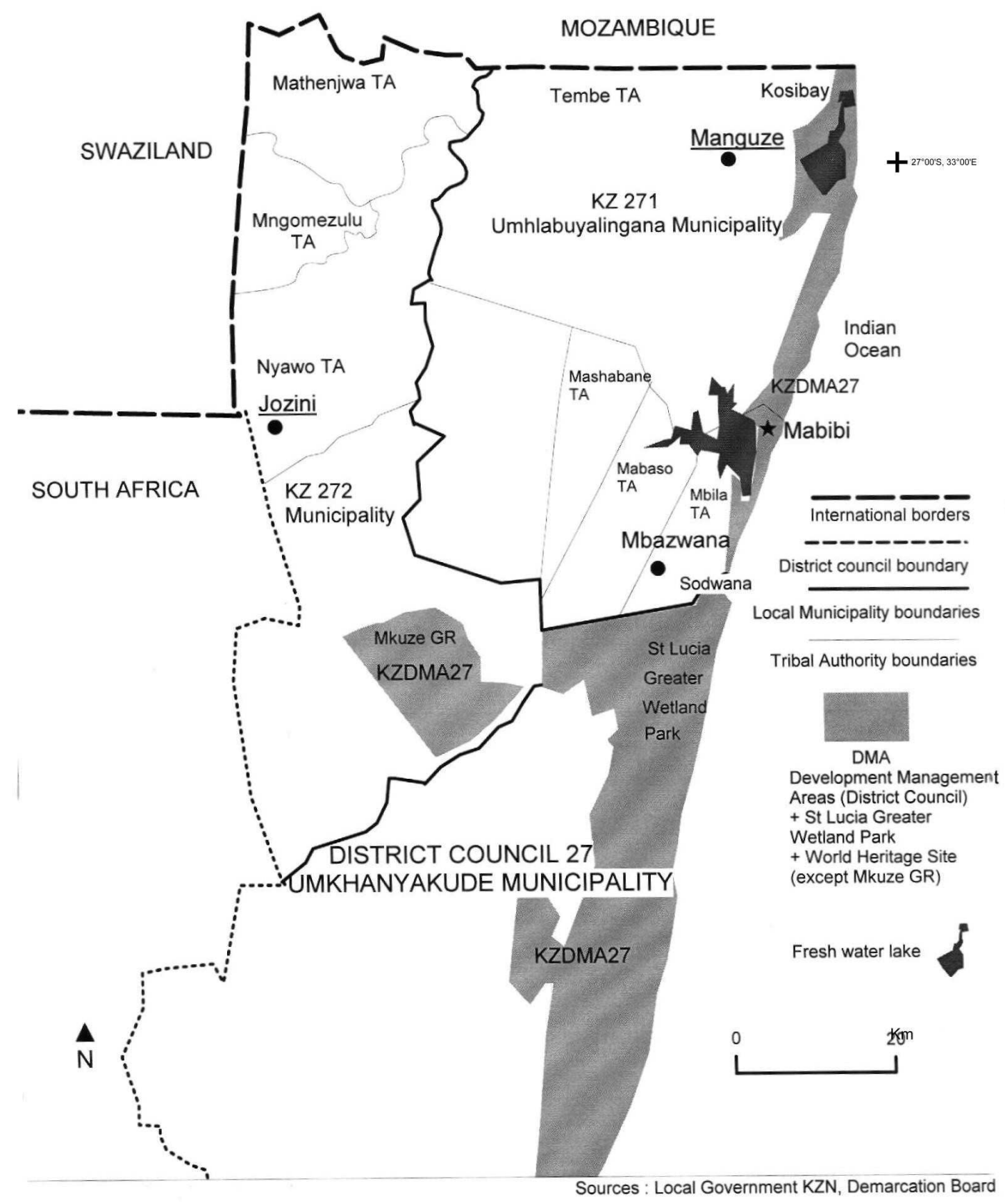




\section{The consequences for development}

At present no progress been made on attracting tourism to this area because these two local government structures (DC 27 and KZ 271) are very new ${ }^{14}$. They await their equitable share from national government. However, this has been delayed in part due to their IFP opposition status (Interview with municipal representatives, Manguzi 20-06-2001). No formal infrastructure exists to accommodate these forms of governance and in order for development to take place, these new local government structures will have to develop their own infrastructures in terms of offices, equipment and financing first.

Therefore, the only effective level of decision-making taking place at Mabibi at the present time is the new authority of the Greater St Lucia Wetland Park (GSLWP), aided by the Lubombo Spatial Development Initiative. A part of the development phase ${ }^{15}$ of GSLWP includes Mabibi: the idea being to promote low intensity, high value ecotourism along the coast and around Lake Sibaya. This necessitates upgrading the sand road from Mbazwana to Mabibi and the provision of a reliable water supply. This proposal is funded by national government as part of the LSDI. However, the ranking of the aims of this project are interesting: The first aim is to promote ecotourism and then to provide benefits to the local community. Currently the LSDI is trying to attract foreign tourism developers to the area. Unfortunately consultation between people and organisations at the national and local levels, especially related to the residents, is very poor (Interview with legal opponents of LSDI, Durban 30-08-2001, arena observation ${ }^{16}$ ). This poor level of consultation could be a source of future conflicts between the local residents and the authorities as new developments will not be accepted or properly used if the community is not part of the decision making process. One can argue that Thonga-Zulu culture is attaching an important value to the formal consultation processes (Felgate 1982).

At the same time, an interesting regulatory body has been created at a provincial level, though it has not formal links to the previous national initiatives. Local boards - with representatives of the different local stakeholders - have been started in some conservation areas of the province to drive locally-based development projects. A local board is being implemented for the whole of the Coastal Forest Reserve, which now part of the GSLWP. These local boards are to be financed by community levies (Sandwith 2001). For example, in Mabibi, the tourists who stay at the campsite will have to pay the community levy. Unfortunately for Mabibi the community levy will not directly benefit community development due to the land ownership problems between the two tribal authorities as the local board for the Coastal Forest Reserve is dealing with the Tembe Tribal Authority (TTA) and the Induna of Mabibi is still under the jurisdiction of the Mbila Tribal Authority (MTA) though the land is still owned by the TTA. It means that the levy is collected at Mabibi but managed by the TTA. The legacy of the past remains strong.

The provincial conservation agency - Kwazulu Natal Wildlife - is trying to resolve the major spatial conflicts that have arisen because of the different uses of natural resources by following new IUCN principles (Mountain 1990). However, the structures which have appeared under the new scheme of governance appear to be detached from these principles. Potential conflicts of interest could be experienced between the local, provincial and national levels, especially now that the area has World Heritage Status. For example, in respect of the

\footnotetext{
${ }^{14}$ And they have to find a way of integration for the Tribal Authority within the councils, a national debate between ANC and IFP.

${ }^{15}$ Phase 2a infrastructure and water project

${ }^{16}$ LSDI meeting within the Mabibi community, 30-03-2001.
} 
strict rules UNESCO imposes regarding new tourism infrastructure developments (UNESCO 2001).

\section{Conclusion}

The spatial competition which has taken place at Mabibi has not had the dramatic expressions that have been observed in other places (AFRA 1990, SPP 1983, Rey 2001); however, it is a matter of concern. The community is living and working within the boundaries of the new Greater St Lucia Wetland Park. It will not be relocated, as happened elsewhere in the past in South Africa (SPP 1983), as the new post-apartheid constitution guarantees the right to people to live on their ancestral land. For this reason, new forms of co-operation need to be created between the park authority, the tourist developers and the residents in order to create a sustainable future for the area and to maximise benefits from any form of development to the community. The new and complex governance framework that is being implemented, in theory addresses this issue. Co-operation could be achieved if the division of powers and functions are clear to all stakeholders, and if every level of governance has sufficient budget to deliver their services. In reality, however, the different organisations do not work together effectively.

One exception to this was the initiative promoted by the provincial conservation agency to implement representative local boards to create a real partnership between local stakeholders and conservation staff. It appears that this is the only formal measure which is trying to resolve the existing spatial conflicts. Unfortunately internal competition between the two traditional authorities is impeding process because of they are competing for funding. The question of legitimacy of traditional leaders and their possible participation within the local government also remains unresolved.

Autonomy within the local community and its ability to drive its future does not seem to have improved. There is large gap between a costly and complex institutional framework and its ability to deliver improvements on the ground. Maybe every stakeholder needs time to be able to understand his or her real rights and duties. The priority is to attract foreign investment to promote this scenically beautiful location as a unique ecotourism and cultural destination under UNESCO rules and regulations. The World Heritage Site Status has perhaps given Mabibi an unexpected positive recognition. However, it is not apparent which philosophy is being use to deliver development - participation or authoritarianism ?

\section{References}

AFRA, 1990, Maputaland : conservation and removals, AFRA, Pietermaritzburg, 60 p.

BARNES J., MORRIS M., 1997, « Kwazulu-Natal's rural institutional environment: Its impact on local service delivery », Development Southern Africa, vol. 14, n², april.

BIERSCHENK T., OLIVIER DE SARDAN J-P., 1997, "Local powers and a distant state in rural central african republic", The Journal of modern african studies, London, vol. 35, n³, p 441 à 468.

BRUTON M.N., 1980, Studies on the ecology of Maputaland, Rhodes University, Durban, 560 p.

COMPAGNON D., CONSTANTIN F., 2000, Administrer l'environnement en Afrique, Karthala - IFRA, 494 p.

CORD, 1991, "Regaining control", chapitre 7, in : Restoring the Land : Environmental change and post Apartheid South-Africa : sous la direction de O. Bennet et W. Davies. - Londres : Panos publication Ltd. 
CROUZEL Y., 1999, La chefferie traditionnelle face à la démocratisation des pouvoirs locaux, Afrique Contemporaine, $\mathrm{n}^{\circ} 192$, p 30-39.

DAVION R.J., 1996, A contribution to understanding contemporary people-environment dynamics : South African approaches in context., Th. : Géographie et Etudes environnementales : Institute of Natural Resources : Pietermaritzburg, $119 \mathrm{p}$.

DRAPER M.,1998, "Zen and the Art of Garden Province Maintenance : the Soft Intimacy of Hard Men in the Wilderness of KwaZulu-Natal, South Africa, 1952-1997", Journal of Southern African Studies, vol. 24, n 4, pp. 801-828.

FELGATE W.S., 1982, The Tembe Thonga of Natal and Mozambique: an ecological approach, Dep. African Studies, University of Natal, Durban, $182 \mathrm{p}$.

FRITZ J-C, 1996. - "L'évolution des politiques de l'environnement en Afrique du Sud. Recomposition territoriale et protection de la nature", Hérodote, $n^{\circ} 82 / 83$, pp. 213-233.

GERVAIS-LAMBONY P., 1997, L'Afrique du Sud et les États voisins. Paris : Armand Colin, Collection U Géographie, $244 \mathrm{p}$

GIRAUT F., 2001, “Borderlands: Remote Areas or Cutting Edge ?”, Newtown Zebra - Ifas research supplement, $\mathrm{n}^{\circ} 20$, september-december 2001, p 14-15.

GOVENDER Y., 2001, Environmental factors maintaining coastal biodiversity in Maputaland, MSC Thesis, surpervised by Prof. Jury, Department of Environmental Studies, University of Zululand, 146 p.

GOVENDER Y., 1999, Impact of conservation measures on community development, Unpublished Honours Thesis, Department of Environmental Studies, University of Zululand, 66 p.

GUYOT S., 2001, Spatial Competition and Environmental Issues on the KwaZulu-Natal Coast: Communities, Social Equity, Economic Growth and Decentralisation, PhD Thesis in Geography (University of Paris X), work in progress.

INNFIELD M.M., 1986 a, Improving Local Support for African Conservation Areas, Institute of Natural Resources, Pietermaritzburg, 43 p.

JURY M. et al., 2001, UNESCO Progress Reports : ecological and human aspects, on request: $<$ mjury@pan.uzulu.ac.za $>$

KOCH E., COCK J., 1991, Going green, People, politics and the environment in South Africa, Cape Town : Oxford University Press.

JUTAS RSC REPORT, 1990, News and views on Regional Services Councils, June.

McINTOSH A., 1995, «The rural local government question in South Africa: prospects for locally based development », Development Southern Africa, vol 12, n³, june.

MOUNTAIN A., 1990, Maputaland: paradise under pressure, Southern Book Publishers, 150 p.

MTHEMBU A., 2001, MABIBI SOCIOECONOMIC SURVEY, communication to the " Power and territories seminar » IRD - University of Zululand, 1-10-2001, Richards Bay

OLIVIER DE SARDAN J-P., 1998, Anthropologie et développement, Essai en socio - anthropologie du changement social, APAD - Karthala, 218 p.

Provincial Gazette of KwaZulu-Natal, 3 july 1997, Local Board for protected areas, p1017-1018

RAMPHELE M., 1991, Environment and change in post-apartheid South Africa, Panos, London, 216 p.

RAMUTSINDELA M., 2001, «Down the post-colonial road: reconstructing the post-apartheid state in South Africa, Political Geography n²0, p57-84, Pergamon 
REY B., 2001, La redéfinition des interfaces des réserves naturelles au KwaZulu-Natal, Afrique du Sud, Mémoire de Maîtrise, Institut de Géographie Alpine, Grenoble, 136 p.

SANDWITH T., 2001, KwaZulu-Natal Wildlife : Strategic Business Plan, document interne KZNW, 23 p.

SPP REPORTS, 1983, Forced removals in South Africa, vol. 1: 120 p., vol. 2: 572

ZALOUMIS, A. \& DREYER, E., 1996, Briefing for Trilateral Meeting between Swaziland, Mozambique and South Africa on Cross Border Agri-tourism Spatial Development Initiatives. CSIR Report.

\section{Internet sources utilised}

South African Tourism (2000) Categories of Protected Areas www.southafrica.net/conservation/categories.html Accessed July 2000

KwaZuku Natal Wildlife (2001) www.rhino.org.za Accessed September 2001

Lumbombo Spatial Initiative (2001) Tourism Potential http://www.lumbombo.org.za/lsdi/tourpolicise.html Accessed September 2001

Maputaland Tourism Alliance (2001) Zulu, Swazi, Thonga http://www.maputaland.co.za/maputaland.html Accessed September 2001

Municipal Demarcation Board (2001) www.demarcation.org.za Accessed September 2001

UNESCO (2001) World Heritage sites www.unesco.org/whc/ Accessed September 2001 